PATTINGALLOANG

CJurnal Pemikiran Pendidikan dan Penelitian Kesejarahan

\title{
Upaya Peningkatan Kemampuan Mengajar Guru Sejarah dengan Menggunakan Model Pembelajaran Kooperatif Tipe STAD SMA Negeri 1 Polongbangkeng Utara Kabupaten Takalar
}

\author{
Nurhayati $^{1}$ \\ 'Pengawas Sekolah Madya Kabupaten Takalar \\ Email: 'nurhayati@gmail.com
}

\begin{abstract}
Abstrak
Penelitian ini adalah penelitian tindakan kelas (classroom action research) yang bertujuan tujuan yang akan di capai dalam pelaksanaan penelitian ini adalah untuk mengetahui kemampuan mengajar guru-guru sejarah dengan menggunakan salah satu model pembelajaran yaitu model kooperatif tipe STAD. Pada kedua guru sejarah yang menjadi responden dalam penelitian ini mengikuti pembimbingan/ pembinaan tentang bagaimana strategi model-model pembelajaran kooperatif diterapkan kedalam RPP termasuk model kooperatif Tipe STAD, sekaligus mampu menerapkan dengan baik didalam Kelas.

Penelitian ini dilakukan dalam dua siklus yaitu siklus I dilakukan 2 kali pertemuan dan siklus II juga dilakukan 2 kali pertemuan, yang dilakukan selama 2 bulan dan ditambah dengan merangkum semua hasil penelitian yang ada. Hasilnya peningkatan belajar peserta didik melalui model kooperatif tipe STAD ini adalah dilihat dari 1) Persepsi awal dan akhir siswa bahwa (a). Pada guru yang mengajar dikelas X.I yakni Ada perubahan sikap belajar siswa terhadap cara mengajar gururnya dari tidak senang sekitar 62,08 persen pada siklus I menjadi sangat senang sekitar 75,86 persen pada siklus II. Ada kenaikan sekitar 13,78 persen. (b). Pada guru yang mengajar dikelas XI.IPA.1 yakni Ada perubahan sikap belajar siswa terhadap cara mengajar gurunya dari tidak senang sekitar 52,77 persen pada sekitar 52,77 persen pada siklus I, menjadi sangat senang sekitar 75 persen pada siklus II, ada kenaikan sekitar 22,23 persen. 2) Kemampuan Mengajar Guru dimana (a). ada perubahan sikap dan cara mengajar guru dikelas X.I dari kategori kurang sekitar 29,5 pada siklus I, menjadi kategori baik sekitar 53,5 pada siklus II. Ada kenaikan skor sekitar 24. Dan (b) ada perubahan sikap dan cara mengajar guru di kelas XI.IPA.1 dari kategori cukup sekitar 35,5 pada siklus I, menjadi kategori baik sekitar 62. Pada siklus II ada kenaikan skor sekitar 26,5. Sehubungan dengan hasil di atas, maka model pembelajaran ini dinilai cukup efektif serta efisien diterapkan dalam mengajar khususnya pada bidang sejarah, dimana mampu meningkatkan minat belajar siswa dan memeotivasi guru dalam berperestasi dalam proses belajar mengajar dikelas.
\end{abstract}

Kata Kunci : Peningkatan, Kemampuan Mengajar Guru Sejarah, model kooperatif tipe STAD.

\begin{abstract}
This research is a classroom action research that aims at the objectives to be achieved in the implementation of this research is to determine the ability of teaching history teachers by using one of the learning models, namely the STAD cooperative model. The two history teachers who were respondents in this study followed the guidance / coaching on how the strategies of cooperative learning models were applied into the lesson plans, including the STAD Type cooperative model, as well as being able to apply well in the classroom.

This research was conducted in two cycles, namely cycle I conducted 2 meetings and cycle II also held 2 meetings, conducted for 2 months and supplemented by summarizing all existing research results. The result is an increase in student learning through the STAD type cooperative model is seen from 1) the students' initial and final perceptions that (a). In teachers who teach in class X.I namely There is a change in student learning attitudes toward the way of teaching the teacher from not happy about 62.08 percent in the first cycle to very happy about 75.86 percent in the second cycle. There was an increase of around 13.78
\end{abstract}

Vol. 7, No.1, April 2020, 93-109|94 
percent. (b). In the teacher who teaches in class XI.IPA.1 ie There is a change in students' learning attitudes towards how to teach their teacher from not happy about 52.77 percent to about 52.77 percent in the first cycle, to be very happy about 75 percent in the second cycle, there was an increase around 22.23 percent. 2) Teachers' Ability to Teach where (a). there is a change in the attitudes and ways of teaching teachers in class X.I from the lack of about 29.5 in the first cycle, to a good category around 53.5 in the second cycle. There was an increase in scores of about 24 . And (b) there was a change in attitude and way of teaching teachers in class XI.IPA.1 from enough categories around 35.5 in cycle I, to a good category of about 62 . In cycle II there was an increase in scores of about 26, 5 In connection with the above results, this learning model is considered quite effective and efficient in teaching, especially in the field of history, which is able to increase student interest in learning and motivate teachers to perform in the teaching and learning process in class.

Keywords: Improvement, History Teacher Teaching Ability, STAD type cooperative model

\section{A. Pendahuluan}

Menghadapi era AFTA, NAFTA, dan AFEC tahun-tahun mendatang yang ditandai dengan persaingan secara terbuka, dengan kondisi SDM kita yang sekarang ini masih dianggao lemah oleh para pakar pendidik kita, maka konsekuensinya akan merugikan bangsa ini. Jadi, tantangan masa yang akan dating ialah meningkatkan daya saing dan keunggulan kompetitif disemua sektor.

Muslimin Nasution (1998), dalam Armai Arif, 2007:2, berkata bahwa SDM yang tangguh adalah SDM yang menguasail Ilmu Pengetahuan dan Tekhnologi (IPTEK).

Permasalahannya sekarang, apakah innstitusi pendidikan kita siap menghasilkan SDM yang mampu bersaing dalam dunia global?. Apakah pengembang kurikulum dan guru-guru siap menghadapi tuntunan kekinian dan masa depan?. Bagaimana guru-guru kita menyiapkan peserta didik agar mereka dapat hidup produktif dan sukses dimasa depan dan keterampilan apa yang diperlukan untuk pekerjaan-pekerjaan di masa depan.

Departemen pendidikan dan kebudayaan nasional telah mencoba menjawab pertanyaan-pertanyaan di atas dengan melakukan perubahan kurikulum, yaitu dari kurikulum berbasis konten menuju pada kurikulum berbasis kompetensi (KBK). Perbedaan mendasar antara kurikulum lama (1994) dengan KBK seperti yang dikemukakan oleh Kwartolo (dalam menggunakan pendekatan materi, syarat materi(overloaded), dan isinya tumpang tindih(over lapping). Sedangkan KBK menggunakan metode pendekatan penguasaan kompetensi tertentu, meterinya sedikit teteapi mendalam, komperhensif dan berkelanjutan, meterinya kontekstual dan sebagainya.

Tujuan-tujuan pendidikan sejarah yang tertuang di dalam kurikulum berbasis kompetensi (KBK) bertujuan agar peserta didik memiliki kemampuan yaitu: Membangun kesadaran peserta didik tentang pentingnya waktu dan tempat yang merupakan sebuah proses dari masa lampau, masa kini, dan masa depan. Melatih daya kritis peseta didik untuk memahami fakta sejarah secara benar dengan didasarkan pada pendekatan ilmiah dan metode keilmuan. Menumbuhkan apresiasi dan penghargaan peserta didik terhadap peningkatan sejarah sebagai bukti peradaban bangsa Indonesia dimasa lampau. Menumbuhkan pemahaman peserta didik terhadap proses terbentuknya bangsa Indonesia melalui sejarah yang panjang dan masih berproses hingga masa kini dan masa yang akan datang. Menumbuhkan kesadaran dalam diri peserta didik sebagai bagian dari bangsa Indonesia yang memiliki rasa bangga dan cinta tanah air yang dapat diimplementasikan dalam berbagai bidang kehidupan baik nasional maupun internasional.

Tujuan-tujuan dia atas, meruapakan suatu tujuan yang bersifat ideal dan mungkin sulit dicapai. Namun yang lebi penting dari tujuantujuan tersebut yakni pembelajran sejarah lebih menekankan pada suatu proses. Kemampuankemanpuan yang diharapkan dimiliki peserta didik, dapat diperoleh melalui suatu proses belajar mengajar yang optimal. Oleh karena itu, guru seyoyanya berusaha membantu peseta didik

Vol. 7, No.1, April 2020, 93-109 |95 
untuk mengkonstruksi pengetahuan dengan kemampuannya sendiri melalui proses internalisasi sehingga pengetahuan tersebut dapat terkonstruksi kembali. Demikian pula, ketika peserta didik bekerja untuk mengkonstruksi pengetahuan baru dengan mengintegrasikan dengan pengetahuan sebelumnya, sebaiknya guru bertindak sebagai fasilitator. Pembelajaran tidak lagi berpusat pada guru ( Teacher Oriented) namun berpusat pada peserta didik ( Student Oriented).

Menurut pandangan konstruksivistik, belajar merupakan suatu proses pembentukan pengetahuan. Pembentukan ini harus dilakukan oleh sibelajar. Ia harus aktif melakukan kegiatan, aktif berfikir, menyusun konsep dan memberi makna tentang hal-hal yang sedang dipelajari. Guru memang dapat dan harus mengambil prakarsa untuk menata lingkungan yang memberi peluang optimal bagi terjadinya belajar, pembelajar sebagai pribadi yang sudah memiliki kemampuan awal sebelum mempelajari sesuatu. Kemampuan awal tersebut masih sangat sederhana atau tidak sesuai dengan pendapat guru, sebaiknya diterima dan dijadikan dasar pembelajaran dan pembimbingan. C.Asri Budingingsih, 2005:59. Karenanya, guru atau pendidik berperan membantu agar proses pengkrontruksian pengetahuan oleh siswa berjalan lancar, guru tidak mentransferkan pengetahuan yang telah dimilikinya, melainkan membantu siswa untuk membentuk pengetahuannya sendiri. Guru dituntut untuk lebih memahami jalan pikiran atau cara pandang siswa dalam belajar. Guru tidak dapat mengklaim bahwa satu-satunya cara yang tepat adalah yang sama dan sesuai dengan kemauan sang guru.

Dari uraian-uraian diatas, untuk mencapai tujuan pembelajaran sejarah, peserta didik harus diberi kesempatan seluas-luasnya untuk mengkontruksi sendiri pengetahuan yang harus dimiliki. Pemberian kesempatan kepada mereka merupakan suatu sumber pembelajaran untuk mereka saling berinteraksi dengan lingkungan belajarnya sehingga dapat membantu memperoleh pemahaman yang lebih tinggi. Menurut (Suradi, 2005), Interaksi sosial kelompok kecil heterogen dapat membantu siswa menjembatani ZPD-nya (Zone Of Proximal Development) kepemahaman yang lebih tinggi.

Pentingnya aktivitas peserta didik dalam pembelajaran sejarah. Menurut Suradi (2005) dimana kelas dapat dipandang sebagai suatu konteks sosial dalam memahami materi dengan cara dikontuksi dan dinegosiasikan. Selain itu kelas merupakan suatu tempat guru dan siswa membangun lingkungan sosial yang interaktif, dengan tujuan utama meningkatkan proses pembelajaran. Siswa bekerja dalam kelompok kecil akan memiliki beberapa keuntungan untuk dapat menyelesaikan permasalahan secara efektif.

Jadi, kualitas pendidikan sangat ditentukan oleh kemampuan sekolah dalam pengelolaan proses pembelajaran dan terlebih khusus lagi adalah proses pembelajaran yang terjadi didalam kelas yang dilakukan oleh guru. Didalam proses pelaksanaan pembelajaran yang terjadi didalam kelas diharapkan guru mampu merubah cara mengajarnya yaitu dari cara lama (Convensional) yang seakan-akan telah membudaya dikalangan guru-guru rumpun IPS, yang selama ini pembelajaran dilakukan berpusat pada guru saja, masih kurang mampu melakukan pembelajaran yang berpusat pada peserta didik.

Dalam pencapaian kemampuan peserta didik sebagaimana yang dikemukakan oleh KTSP Tahun 2006, mustahil akan tercapai jika tidak dengan perbaikan sistem pembelajaran yang dimaksud sebagaimana permendiknas no. 41 Tahun 2007 tentang standar proses pada dua butir dari beberapa butir pelaksanaan pembelajaran yaitu menggunakan beragam pendekatan pembelajaran, dan menfasilitasi peserta didik dalam pembelajaran kooperatif dan kolaboratif.

Dipandang perlu guru melakukan atau menindak lanjuti isi dari permendiknas nomor 41 tahun 2007 diatas agar peserta didik dalam kegiatan proses pembelajaran dikelas tidak merasa jenuh. Tapi sayang, dari hasil pengamatan penulis (Peneliti) pada sekolah-sekolah binaan selama kurang lebih satu semester pada semester ganjil 2015 dan memasuki semester genap tahun 2016 bahwa program administrasi perangkat pembelajaran yang telah dibuat oleh guru-guru rumpun mata pelajaran IPS menunjukkan : 1). Pada umumnya guru-guru IPS termasuk guru

Vol. 7, No.1, April 2020, 93-109 |95 
sejarah masih kurang mampu menggunakan metode bervariasi dalam proses belajar mengajar dikelas. 2). Perangkat pembelajaran yang dibuatnya diperiksa oleh supervisor sebelum disupervisi dikelas, Nampak guru yang mengajar baik dikelas X, XI, dan di kelas XII tiap semester untuk tiap kompetensi dasar (KD) tidak ada tercantum model pembelajaran yang bervariasi sesuai dengan tuntutan kurikulum berbasis kompetensi (KBK), dan masih sulit merancang suatu bentuk pembelajaran yang efektif dalam kegiatan kerja kelompok. Dari uraian-uraian diatas maka penelitian tindakan sekolah ini (PTS) yang dilakukan oleh peneliti diberi judul " Upaya Peningkatan Kemampuan Mengajar Guru Sejarah Dengan Menggunakan Model Pembelajaran Koperatif Tipe Stad Pada Sma Negeri 1 Polongbangkeng Utara" dalam bentuk makalah di ketengahkan kepada khalayak banyak, terkhusus kepada teman-teman seprofesi, guna saling menimbah pemahaman tentang penelitian tindakan sekolah.

Berdasarkan latar belakang makalah di atas, maka makalah utama yang menjadi perhatian dalam penelitian ini adalah, "Bagaimana tingkat kemampuan mengajar guruguru sejarah dengan menggunakan model pembelajaran kooperatif tipe STAND pada SMA Negeri 1 Polongbangkeng utara”. tujuan yang akan di capai dalam pelaksanaan penelitian ini adalah untuk mengetahui kemampuan mengajar guru-guru sejarah dengan menggunakan salah satu model pembelajaran yaitu model kooperatif tipe STAD.

\section{B. Kajian Pustaka, Kerangka Pikir}

1. Kurikulum Tingkat Satuan Pendidikan Tahun 2006

Pengembangan dan pelaksanaan KTSP yang harus dilakukan oleh satuan pendidikan adalah sebagai implementasi peraturan menteri Pendidikan Nasional Republik Indonesia nomor 22 dan 23 Tahun 2006 tentang standar isi dan standar kompetensi kelulusan untuk satuan pendidikan dasar dan menengah.

Kurikulum tingkat satuan pendidikan dikembangkan berdasarkan pada standar isi dan standar kompetensi lulusan serta berpedoman pada panduan penyusunan kurikulum yang disusun oleh Badan Standar Nasional Pendidikan (BNSP), dengan memperhatikan pertimbangan komite sekolah dengan prinsipprinsip sebagai berikut:

1. Berpusat pada potensi, perkembangan, kebutuhan, dan kepentingan peserta didik dan lingkungannya.

2. Beragam dan terpadu, yang berarti bahwa KTSP disusun sesuai dengan karakteristik peserta didik, kondisi daerah, jenjang dan jenis pendidikan, serta menghargai dan tidak diskriminatif terhadap perbedaan agama, suku budaya, adat istiadat, status sosial ekonomi dan gender.

3. Tanggap terhadap perkembangan ilmu pengetahuan, tekhnologi dan seni.

4. Relevan dengan kebutuhan kehidupan masa kini dan masa datang.

5. Belajar sepanjang hayat dan

6. Seimbang antara kepentingan nasional dan daerah.

KTSP merupakan salah satu bentuk realisasi kebijakan realisasi kebijakan desentralisasi di bidang pendidikan agar kurikulum benar-benar sesuai dengan kebutuhan pengembangan potensi peserta didik di sekolah yang bersangkutan di masa sekarang dan yang akan datang dengan mempertimbangkan kepentingan lokal, nasional dan tuntutan global dengan semangat manajemen berbasis sekolah.

Kegiatan pembelajaran pada KTSP melibatkan peserta didik dalam proses mental dan fisik melalui interaksi antar peserta didik, peserta didik dengan guru lingkungan, dan sumber belajar lainnya dalam rangka pencapaian kompetensi dasar. Kegiatan yang dimaksud dapat terwujud melalui penggunaan pendekatan pembelajaran yang bervariasi dan berpusat pada peserta didik. Kegiatan pembelajaran harus mengembangkan kecakapan hidup yang perlu dikuasai oleh peserta didik.

Kegiatan pembelajaran disusun untuk memberikan bantuan kepada peserta didik, khususnya guru, agar dapat melaksanakan proses pembelajaran secara profesional. Kegiatan pembelajaran memuat rangkaian kegiatan yang harus dilakukan oleh peserta

Vol. 7, No.1, April 2020, 93-109|96 
didik secara berurutan untuk mencapai kompetensi dasar, baik aspek kognitif, psikomotorik maupun aspek nilai dan sikap. Karena proses belajar mengajar adalah proses komunikasi yang sudah barang tentu memiliki hambatan-hambatan terhadap siswa dalam menerima pesan, baik hambatan psikologis, faktor fisik, kultural maupun hambatan yang disebabkan oleh faktor lingkungan. Untuk meminimalkan hambatan-hambatan tersebut maka diperlukan suatu model pembelajaran yang aktif, inovatif, kreatif, enak dan menyenangkan.

Dari uraian diatas dan dihubungkan dengan permendiknas No. 41 Tahun 2007, sebagaimana telah diuraikan pada bab sebelumnya di salah satu butir pelaksanaan pembelajaran mengatakan bahwa guru hendaknya mampu menfasilitasi peserta didik dalam pembelajaran kooperatif dan kolaboratif.

Kurikulum Tingkat Satuan Pendidikan (KTSP) 2006, tidak kaku dari segi pelaksanaan pembelajaran, artinya seorang guru sejarah dalam menyusun rencana pembelajaran yang dituangkan dalam program semester, silabus dan RPP dapat menyelipkan satu, dua atau lebih model-model pembelajaran yang disesuaikan dengan pembelajaran disesuaikan dengan keadaan atau tuntutan Standar Kompetensi (SK) dan Kompetensi Dasar (KD), jangan hendaknya setiap Kompetensi Dasar (KD) dalam setiap satu semester disusun hanya dengan menggunakan satu metode yaitu metode konvensional (cara lama yang berulang).

\section{Belajar dengan Cara Kooperatif}

Pencapaian tujuan pembelajaran yang lebih optimal yang dilakukan oleh guru hanya dapat dicapai apabila dalam proses pembelajaran terjadi interaksi aktif antara siswa ke guru, dan antara siswa ke sesama siswa, untuk menciptakan hal tersebut diatas, guru harus menerapkan salah satu model dari beberapa model pembelajaran kooperatif.

Pembelajaran kooperatif unggul dalam membantu siswa dalam memahami konsepkonsep dan sangat berguna untuk membantu siswa menumbuhkan kemampuan, kerjasama, berpikir kritis, dan kemampuan komunikasi. (Suradi, 2006:2).
Pendekatan konstruktivis dalam pengajaran menerapkan model pembelajaran kooperatif secara ekstensif, atas dasar teori bahwa siswa akan lebih mudah menemukan dan memahami konsep-konsep itu dengan temanya. (Slavin,1995).

Sedangkan, Lungdren (1994), mengemukakan bahwa dari hasil penelitian menunjukkan teknik-teknik pembelajaran kooperatif lebih banyak meningkatkan hasil belajar daripada pengalaman-pengalaman belajar individu dan kompetitif.

Sementara Thomson et-al (1995), jika dipandang dari segi aspek sosial, pembelajaran kooperatif turut menambah unsur-unsur interaktif sosial pada pembelajaran. Pembelajaran kooperatif adalah suatu pembelajaran dengan menekankan pada aspek sosial. Siswa belajar dalam kelompok-kelompok kecil dan saling membantu satu sama lain. Kelas disusun dalam kelompok yang terdiri dari 4 atau 5 siswa dengan kemampuan yang heterogen adalah terdiri dari kemampuan siswa, jenis kelamin dan suku. Dalam pembelajaran kooperatif struktur tugas mengacu pada dua hal, yaitu cara pembelajaran yang diorganisasikan dalam bentuk kelompok, dan jenis kegiatan dilaksanakan dengan diskusi, lembar kerja siswa dan negosiasi. Struktur tujuan mengacu kepada keberhasilan bersama antara semua anggota kelompok, sehingga struktur penghargaan yang diberikan adalah penghargaan kelompok. Ratumanan (2000) dalam pembelajaran kooperatif, siswa bekerjasama dalam kelompok-kelompok kecil untuk mempelajari materi akademik dan keterampilan antar pribadi. Anggota-anggota kelompok bertanggungjawab atas ketuntasan tugas-tugas kelompok dan untuk mempelajari materi itu sendiri. Aktivitas siswa yaitu, mengikuti penjelasan guru secara aktif, bekerjasama menyelesaikan tugas dalam kelompok, memberikan penjelasan kepada teman kelompok, mendorong teman kelompok berpartisipasi aktif dan berdiskusi.

Agar pembelajaran dapat berlangsung secara efektif siswa diberi lembar kerja. Lembar Eksplorasi Siswa (LEKS), lembar kerja ini berisikan beberapa pertanyaan, peserta didik diharapkan dapat/mampu mengamati,

Vol. 7, No.1, April 2020, 93-109 
PATTINGALLOANG

(OJurnal Pemikiran Pendidikan dan Penelitian Kesejarahan

mencermati kehendak pernyataan-pernyataan tersebut. Kedua, Lembar Elaborasi Siswa (LEBS) lembar kerja ini berisikan satu atau lebih Wacana / bacaan mereka bekerja secara bersaing dalam kelompok menyelesaikan tugas-tugas sampai mencapai ketuntasan belajar. Kelompok yang mengumpulkan banyak nilai diberi penghargaan.

Model-model pembelajaran inovatif yang dikeluarkan oleh LPMP Makassar, September 2005, berbentuk lembaran kopian tersebut, peneliti mengkopi dari seorang teman guru sejarah yang baru ikut pelatihan terintegrasi berbaris kompetensi.

\section{Kooperatif Tipe STAD}

Dari sekian banyak model pembelajaran yang penulis kopi dari teman guru sejarah tersebut, peneliti mencoba mengkaji model pembelajaran kooperatif tipe STAD yaitu Student Team Achievement Divisions, karena tipe ini merupakan salah satu tipe pembelajaran kooperatif yang paling sederhana untuk diterapkan, apa lagi disekolah ini banyak guru yang baru terangkat PNS belum tahu cara kerja tipe STAD. Tipe model ini disponsori oleh Slavin 1995.

Guru menyajikan pelajaran dan kemudian siswa bekerja didalam kelompok mereka untuk memastikan bahwa seluruh anggota kelompok telah menguasai materi pelajaran tersebut. Akhirnya kepada seluruh kelompok diberikan tes tentang materi itu. Pada waktu tes, mereka tidak dapat saling membantu. Tim yang mencapai kriteria tertentu diberikan penghargaan atau ganjaran lain.

Adapun tahap-tahap pembelajaran kooperatif tipe STAD dapat dilihat pada fase-fase berikut : Sintaks Model Pembelajaran Kooperatif Tipe STAD, Tabel 1:

\begin{tabular}{|l|l|}
\hline \multicolumn{1}{|c|}{ Fase } & \multicolumn{2}{|c|}{ Tingkah Laku Guru } \\
\hline Fase I & $\begin{array}{l}\text { Guru menyampaikan } \\
\text { tujuan pembelajaran }\end{array}$ \\
Menyampaiakan & $\begin{array}{l}\text { (indicator hasil belajar), } \\
\text { tujuan dan } \\
\text { memotivasi siswa memotivasi siswa, } \\
\text { guru mengaitkan pelajaran } \\
\text { sekarang dengan yang } \\
\text { terdahulu. }\end{array}$ \\
\hline
\end{tabular}

\begin{tabular}{|c|c|}
\hline $\begin{array}{l}\text { Fase II } \\
\text { Menyajikan } \\
\text { informasi }\end{array}$ & $\begin{array}{lr}\text { Guru } & \text { menyajikan } \\
\text { informasi kepada siswa } \\
\text { dengan jalan demonstrasi } \\
\text { atau lewat bacaan } \\
\text { (Wacana) }\end{array}$ \\
\hline $\begin{array}{l}\text { Fase III } \\
\text { Mengorganisasikan } \\
\text { siswa kedalam } \\
\text { kelompok- } \\
\text { kelompok belajar }\end{array}$ & $\begin{array}{l}\text { Guru menjelaskan kepada } \\
\text { siswa cara membentuk } \\
\text { kelompok belajar, guru } \\
\text { mengorganisasikan siswa } \\
\text { kedalam kelompok- } \\
\text { kelompok belajar (seriap } \\
\text { kelompok beranggotakan } \\
\text { 4-5 orang yang harus } \\
\text { heterogen terutama jenis } \\
\text { kelamin dan kemampuan } \\
\text { siswa). }\end{array}$ \\
\hline $\begin{array}{l}\text { Fase IV } \\
\text { Membimbing } \\
\text { kelompok bekerja } \\
\text { dan belajar }\end{array}$ & $\begin{array}{l}\text { Guru membimbing } \\
\text { kelompok-kelompok } \\
\text { belajar pada saat siswa } \\
\text { mengerjakan tugas. }\end{array}$ \\
\hline $\begin{array}{l}\text { Fase V } \\
\text { Evaluasi }\end{array}$ & $\begin{array}{l}\text { Guru mengevaluasi hasil } \\
\text { belajar tentang materi yang } \\
\text { telah dipelajari atau } \\
\text { meminta } \\
\text { mempresentasikan hasil } \\
\text { kerjanya kemudian } \\
\text { dilanjutkan dengan diskusi/ } \\
\text { tanya jawab. }\end{array}$ \\
\hline $\begin{array}{l}\text { Fase IV } \\
\text { Memberikan } \\
\text { penghargaan }\end{array}$ & $\begin{array}{lr}\text { Guru } & \text { memberikan } \\
\text { penghargaan } & \text { kepada siswa } \\
\text { yang berprestasi untuk } \\
\text { menghargai upaya dan } \\
\text { hasil belajar } & \text { siswa secara } \\
\text { individu } & \text { maupun } \\
\text { kelompok } & \end{array}$ \\
\hline
\end{tabular}

4. Kerangka pikir

Peran peserta didik akan lebih aktif memainkan perannya jika guru mampu menciptakan atau merancang pembelajaran yang aktif, inovatif, kreatif, enak dan menyenangkan. Untuk itu penggunaan model atau pendekatan

Vol. 7, No.1, April 2020, 93-109 |98 
pembelajaran yang sesuai dengan bahan ajar atau materi yang diajarkan akan dapat membantu peserta didik dalam mencapai tujuan belajarnya.

Proses pembelajaran kooperatuf tipe STAD berlangsung secara alamiah dalam bentuk kegiatan peserta didik bekerja dan mengalami, bukan lago transfer pengetahuan dan keterampilan dari guru ke siswa. Peserta didik perlu mengerti apa makna belajar, apa manfaatnya, bagaimana cara mencapainya. Peserta didik harus menyadari apa yang mereka pelajari hari ini maka berguna di masa depan. Dalam upaya ini, guru hanya bertindak sebagai pengarah, pembimbing, mediator dan fasilitator, dengan konsep pembelajaran ini. Hasil pembelajaran akan lebih bermakna dan berkesan bagi peserta didik sehingga hasil belajarnya dapat ditingkatkan.

\section{Metode Penelitian}

a. Jenis Penelitian

Jenis penelitian ini disebut juga kaji tindak berbasis kelas peneliti mengamati kegiatan guru dan peserta didik dalam proses pembelajaran. Tindakan dilakukan dengan dua siklus berdasarkan pendapat Kemmis dan MC. Taggart 1998 dalam Suharsini Arikunto 2005:6, yang dimulai dari perencanaan, pelaksanaan, pengamatan dan refleksi.

b. Subjek Penelitian

Subjek penelitian dalam penelitian tindakan sekolah ini ada 2 orang guru sejarah yang masing-masing mengajar di kelas X.I dengan jumlah siswa ada 29 orang dan di kelas X.I IPA 1 dengan jumlah siswa ada 36 orang.

c. Teknik Pengumpulan Data

Ada beberapa langkah yang ditempuh peneliti dalam melakukan pengumpulan data yaitu: 1). Membuat quesioner persepsi awal siswa. 2). Membuat lembar observasi kemampuan mengajar. 3). Membuat lembar observasi aktivitas siswa. 4). Membuat lembar quesioner persepsi akhir siswa.

1. Quesioner persepsi awal siswa bertujuan untuk mengetahui sampai dimana pemahaman dan pengetahuan peserta didik terhadap cara mengajar gurunya selama ini, kemudian dilakukan tindakan terhadap kedua guru sejarah tersebut. Namun sebelumnya peneliti telah bernegosiasi dengan Kepala Sekolah dan guruguru yang akan diamati serta guru yang akan mengajar sesudahnya yaitu jam mengajarnya diambil 10 menit dalam setiap tindakan pada sikluas I dan II.

2. Lembar observasi kemampuan mengajar guru adalah instrumen atau alat ukur yang digunakan oleh peneliti atau pengamat I dan pengamat II (pengawas pendamping) dalam menilai kegiatan strategi pembelajaran guru dikelas.

3. Lembar observasi aktivitas peserta didik, diarahkan kepada peserta didik dalam kegiatannya mengikuti proses pembelajaran, bertujuan untuk mengetahui bagaimana keadaan aktivitas pserta didik selama proses pembelajaran berlangsung baik pada siklus pertama dan siklus kedua.

4. Lembar quesioner persepsi akhir bertujuan agar peserta didik mampu memberikan informasi hasil mengenai kesan mereka terhadap proses pembelajaran yang telah dilakukan oleh gurunya.

E. Indikator Kemampuan Mengajar Guru

Indikator kemampuan mengajar guru dalam penelitian ini digambarkan sebagai berikut:

Setelah didalam kelas guru mengontrol peserta didik dan sesaat melakukan kontak mata, lalu menyuruh ketua kelas menyiapkan tujuan pembelajaran dan mengaitkan pengetahuan sebelumnya dengan materi yang diajarkan. Kemudian satu, dua orang peserta didik disuruh bertanya lalu guru memberi motivasi peserta didik agar bersaing dalam belajar. Guru mendistribusi lembaran kerja siswa atau leks yang berisikan beberapa pertanyaan/pernyataan. Peserta didik disuruh mengamati LEKS tersebut dan menyruh bertanya kalau ada pertanyaan. Guru mengorganisasikan peserta didik dalam kelompok bekerja belajar yang beranggotakan 4 atau 5 orang dengan cara peserta didik paling kanan mulai menghitung 1,2,3,4, kemudian dilanjutkan lagi dengan peserta didik berikutnya 1,2,3,4, begitu seterusnya hingga terbentuk beberapa kelompok yang heterogen. Setelah kelompok terbentuk, guru membagikan Lembar Observasi Siswa (LEBS) yang berisikan satu atau lebih

Vol. 7, No.1, April 2020, 93-109 
wacana. Peserta didik disuruh menemukan jawaban atas pertanyaan yang pada Lembar Kerja Siswa (LEKS) yang diterima sebelumnya. Guru membimbing kelompok bekerja dan belajar dengan berjalan mengelilingi tiap kelompok hanya kepada kelompok yang bertanya. Kemudian guru memberikan instruksi kegiatan bekerja kelompok dihentikan, lalu guru menyuruh peserta didik memperhatikan beberapa pertanyaan yang akan dibacakan kemudian (dikondisikan sesuai dengan waktu, 5 atau 10 pertanyaan). Guru memberi kesempatan tiap kelompok untuk menjawab, kelompok yang kurang mampu menjawab di kepada kelompok yang lain menjawabnya, nilai yang diberikan kepada peserta didk menggunakan rentang nilai skor 1 sampai 4 . Guru memberikan penghargaan kepada kelompok yang mengumpulkan nilai terbanyak.

\section{Hasil Penelitian dan Pembahasan \\ 1) Hasil penelitian}

1. Sekilas gambaran umum lokasi penelitian

SMA Negeri 1 Polongbangkeng utara kabupaten Takalar lebih $10 \mathrm{~km}$ dari Ibukota Kabupaten dari jalan poros Makassar-Takalar, lalu dari poros Makassar belok kanan menjorok masuk lebih kurang dari dua $\mathrm{km}$.

SMA Negeri 1 Polongbangkeng utara dibangun awa tahun 2002, kepala sekolah waktu itu Drs. H. Syarifuddin Bangsawan, lalu dilanjutkan oleh Drs. Muh.Rivai pada tahun 2009. Tiga tahun kemudian dimutasi masuk pengawas sekolah, lalu dilanjutkan oleh Dra.Nur Ida Djalil sampai sekarang.

Jumlah kelas yang ada seluruhnya ada 20 kelas, masing-masing kelas X. 8 Ruangan Kelas XI dan XII masing-masing 6 ruangan dan jum;ah siswa seluruhnya ada 589 orang siswa, perempuan berjumlah 324 dan pria ada 265 .

Jumlah guru-guru yang statusnya pegawai negeri sipil (PNS) ada 43 orang guru, dan berstatus honorer ada 8 orang. Guru yang bergelar strata satu (S1) ada 36 orang. Dan bergelar strata dua (S2) ada 7 orang. Ada sekitar lebih 10 persen guru-guru SMA Negeri 1 Polot bertempat tinggal dimakassar dan sungguminasa kab. Gowa, dan lebih dari 80 persen bertempat tinggl di Takalar. Adapun jumlah staf tata usaha ada 3 orang PNS dan 14 orang Non PNS.

SMA Negeri 1 Polongbangkeng utara (polot) masih menggunakan Kurikulum Tingkat Satuan Pendidikan (KTSP) Tahun 2006. dan memiliki visi sekolah. " bernuansa religius, kritis dalam berfikir, Profesional dalam layanan. Unggul dalam prestasi “. sedangkan misi sekolah yaitu " Meningkatkan keimanan dan ketaqwaan kepada Tuhan Yang Maha Esa

Serta mengembangkan era berpikir kritis, ilmiah dan rasional dalam mengantisipasi perkembangan IPTEK dan budaya untik menyongsong era globalisasi”.

2. Penyajian dan Analisis Data

Pada bagian bab ini akan dideskripsikan hasil analisis data dan interpretasinya, untuk mengungkapkan persepsi awal siswa, kemampuan mengajar guru, aktivitas siswa dan persepsi akhir siswa pada masing-masing siklus:

1. Siklus Satu (I)

a. Tabel 3. Persepsi awal siswa pada guru yang mengajar dikelas X. Satu

\begin{tabular}{|c|c|c|c|c|c|}
\hline Kelas & Siswa & Obsion & $\begin{array}{c}\text { Persepsi } \\
\text { Siswa }\end{array}$ & Persen & Ket \\
\hline X.I & 29 & A & - & - & \\
& & B & 7 & 24,13 & \\
& & C & 4 & 13,79 & \\
& & D & 18 & 62,08 & \\
\hline
\end{tabular}

Sumber: Hasil olahan data lampiran I (N: 29 siswa)

b. Tabel 4. Persepsi awal siswa pada guru yang mengajar dikelas XI.IPA.I

\begin{tabular}{|c|c|c|c|c|c|}
\hline Kelas & $\begin{array}{c}\text { Sisw } \\
\mathrm{a}\end{array}$ & $\begin{array}{c}\text { Obsio } \\
\mathrm{n}\end{array}$ & $\begin{array}{c}\text { Persep } \\
\mathrm{si} \\
\text { Siswa }\end{array}$ & $\begin{array}{c}\text { Perse } \\
\mathrm{n}\end{array}$ & $\begin{array}{c}\text { Ke } \\
\mathrm{t}\end{array}$ \\
\hline XI.IPA & 36 & $\mathrm{~A}$ & 2 & 5,55 & \\
.I & & $\mathrm{B}$ & 8 & 22,22 & \\
& & $\mathrm{C}$ & 7 & 19,44 & \\
& & $\mathrm{D}$ & 19 & 52,77 & \\
\hline
\end{tabular}

Sumber: Hasil olahan data lampiran 3 (N: 36 siswa) 
PATTINGALLOANG

(OJurnal Pemikiran Pendidikan dan Penelitian Kesejarahan

c. Table 5. Indikator kemampuan mengajar guru pada kelas X. Satu

\begin{tabular}{|c|c|c|c|c|}
\hline $\begin{array}{c}\text { Skor } \\
\text { kegiata } \\
\text { n awal }\end{array}$ & $\begin{array}{c}\text { Skor } \\
\text { kegiata } \\
\text { n inti }\end{array}$ & $\begin{array}{c}\text { Skor } \\
\text { kegiata } \\
\text { n akhir }\end{array}$ & $\begin{array}{c}\text { Jumla } \\
\text { h }\end{array}$ & $\begin{array}{c}\text { Pengama } \\
\text { t }\end{array}$ \\
item 1 & item 7 & item 15 & & \\
s/d 6 & s/d 14 & s/d 17 & & \\
\hline 9 & 14 & 5 & 28 & I \\
10 & 16 & 5 & 31 & II \\
\hline
\end{tabular}

Sumber: Hasil olahan data lampiran 3 (N: 29 siswa)

d. Table 6. Indikator kemampuan mengajar guru pada kelas XI.IPA.I Siklus I

\begin{tabular}{|c|c|c|c|c|}
\hline $\begin{array}{c}\text { Skor } \\
\text { kegiata } \\
\mathrm{n} \text { awal } \\
\text { item 1 }\end{array}$ & $\begin{array}{c}\text { Skor } \\
\text { kegiata } \\
\mathrm{n} \text { inti } \\
\text { item 7 } \\
\mathrm{s} / \mathrm{d} 6\end{array}$ & $\begin{array}{c}\text { Skor } \\
\text { kegiata } \\
\mathrm{n} / \mathrm{d} \text { 14 } 14\end{array}$ & $\begin{array}{c}\text { Jumla } \\
\text { item } \\
15 \mathrm{~s} / \mathrm{d} \\
17\end{array}$ & $\begin{array}{c}\text { Pengam } \\
\text { at }\end{array}$ \\
\hline 13 & 16 & 5 & 34 & \\
15 & 18 & 4 & 37 & I \\
\hline
\end{tabular}

Sumber: Hasil olahan data lampiran 4 (N: 36 siswa)

e. Table 7. Aktivitas siswa pada guru yang mengajar dikelas X. Satu Siklus I

\begin{tabular}{|l|l|c|c|c|c|}
\hline No & Uraian & \multicolumn{2}{|c|}{$\begin{array}{c}\text { Pengamat } \\
\text { I }\end{array}$} & \multicolumn{2}{|c|}{ II } \\
\cline { 2 - 5 } & $\begin{array}{l}\text { Freku } \\
\text { ensi }\end{array}$ & Persen & $\begin{array}{c}\text { Fre } \\
\text { kue } \\
\text { nsi }\end{array}$ & Persen \\
\hline 1 & $\begin{array}{l}\text { Bermai } \\
\text { n-main, } \\
\text { sibuk } \\
\text { dengan } \\
\text { ceritany } \\
\text { a, tidur- } \\
\text { tiduran, } \\
\text { melamu } \\
\text { n atau } \\
\text { malas- } \\
\text { malasan }\end{array}$ \\
2 & $\begin{array}{l}\text { Menyel } \\
\text { esaikan } \\
\text { masalah } \\
\text { secara } \\
\text { mandiri }\end{array}$ & 23 & 65,51 & 21 & 72,41 \\
\hline
\end{tabular}

\begin{tabular}{|l|l|l|l|l|l|}
\hline 3 & $\begin{array}{l}\text { Menyel } \\
\text { esaikan } \\
\text { masalah } \\
\text { secara } \\
\text { kelomp } \\
\text { ok }\end{array}$ & 0 & 0 & 0 & 0 \\
\hline 4 & $\begin{array}{l}\text { Melaku } \\
\text { kan } \\
\text { diskusi } \\
\text { atau } \\
\text { bertany } \\
\text { a }\end{array}$ & 0 & 0 & 0 & 0 \\
\hline
\end{tabular}

Sumber: Hasil olahan data lampiran 5 (N: 29 siswa)

f. Table. 8. Aktivitas siswa pada guru yang mengajar dikelas XI.IPA.I

\begin{tabular}{|c|c|c|c|c|c|}
\hline \multirow[t]{3}{*}{ No } & \multirow[t]{3}{*}{ Uraian } & \multicolumn{4}{|c|}{ Pengamat } \\
\hline & & \multicolumn{2}{|c|}{ I } & \multicolumn{2}{|c|}{ II } \\
\hline & & $\begin{array}{c}\text { Freku } \\
\text { ensi }\end{array}$ & $\begin{array}{c}\text { Pers } \\
\text { en }\end{array}$ & $\begin{array}{c}\text { Freku } \\
\text { ensi }\end{array}$ & $\begin{array}{c}\text { Pers } \\
\text { en }\end{array}$ \\
\hline 1 & $\begin{array}{l}\text { Bermai } \\
\text { n-main, } \\
\text { sibuk } \\
\text { dengan } \\
\text { ceritan } \\
\text { ya, } \\
\text { tidur- } \\
\text { tiduran } \\
\text { melam } \\
\text { un atau } \\
\text { malas- } \\
\text { malasa } \\
\text { n }\end{array}$ & 23 & $\begin{array}{c}63,8 \\
8\end{array}$ & 26 & $\begin{array}{c}72,2 \\
2\end{array}$ \\
\hline 2 & $\begin{array}{l}\text { Menyel } \\
\text { esaikan } \\
\text { masala } \\
\text { h } \\
\text { secara } \\
\text { mandir } \\
\text { i }\end{array}$ & 25 & $\begin{array}{c}69,4 \\
4\end{array}$ & 28 & $\begin{array}{c}77,7 \\
7\end{array}$ \\
\hline 3 & $\begin{array}{l}\text { Menyel } \\
\text { esaikan } \\
\text { masala } \\
\text { h } \\
\text { secara } \\
\text { kelomp }\end{array}$ & 0 & 0 & 0 & 0 \\
\hline
\end{tabular}

Vol. 7, No.1, April 2020, 93-109 |101 
PATTINGALLOANG

(CJurnal Pemikiran Pendidikan dan Penelitian Kesejarahan

\begin{tabular}{|c|c|c|c|c|c|}
\hline & ok & & & & \\
\hline 4 & $\begin{array}{l}\text { Melaku } \\
\text { kan } \\
\text { diskusi } \\
\text { bertany } \\
\text { a }\end{array}$ & () & () & () & () \\
\hline
\end{tabular}

Sumber: Hasil olahan data lampiran 6 (N: 36 siswa)

II.Siklus Dua (II)

a. Tabel 9. Indikator kemampuan mengajar guru pada kelas X Satu Siklus II

\begin{tabular}{|c|c|c|c|c|}
\hline $\begin{array}{c}\text { Skor } \\
\text { kegiata } \\
\mathrm{n} \text { awal } \\
\text { item 1 } \\
\mathrm{s} / \mathrm{d} 6\end{array}$ & $\begin{array}{c}\text { Skor } \\
\text { kegiata } \\
\mathrm{n} \text { inti } \\
\text { item 7 } \\
\mathrm{s} / \mathrm{d} 14\end{array}$ & $\begin{array}{c}\text { Skor } \\
\text { kegiata } \\
\mathrm{n} \text { akhir } \\
\text { item } \\
15 \mathrm{~s} / \mathrm{d} \\
17\end{array}$ & $\begin{array}{c}\text { Jumla } \\
\mathrm{h}\end{array}$ & $\begin{array}{c}\text { Pengam } \\
\text { at }\end{array}$ \\
\hline 19 & 23 & 10 & 52 & \\
\hline 21 & 23 & 11 & 55 & II \\
\hline
\end{tabular}

Sumber: Hasil olahan data lampiran 7 (N: 29 Siswa)

b. Tabel 10. Indikator kemampuan mengajar guru pada kelas XI IPA I Siklus II

\begin{tabular}{|c|c|c|c|c|}
\hline $\begin{array}{c}\text { Skor } \\
\text { kegiata } \\
\text { n awal } \\
\text { item 1 } \\
\text { s/d 6 }\end{array}$ & $\begin{array}{c}\text { Skor } \\
\text { kegiata } \\
\text { n inti } \\
\text { item 7 } \\
\text { s/d 14 }\end{array}$ & $\begin{array}{c}\text { Skor } \\
\text { kegiata } \\
\text { n akhir } \\
\text { item } \\
15 \mathrm{~s} / / \mathrm{d} \\
17\end{array}$ & $\begin{array}{c}\text { Jumla } \\
\mathrm{h}\end{array}$ & $\begin{array}{c}\text { Pengam } \\
\text { at }\end{array}$ \\
\hline B & 26 & 11 & 59 & I \\
\hline 23 & 31 & 11 & 65 & II \\
\hline
\end{tabular}

Sumber: Hasil olahan data lampiran 8 (N: 36 Siswa)

c. Tabel 11. Aktivitas siswa pada guru yang mengajar dikelas X Satu Siklus II

\begin{tabular}{|c|l|c|c|c|c|}
\hline \multirow{2}{*}{ No } & \multirow{2}{*}{ Uraian } & \multicolumn{4}{|c|}{ Pengamat } \\
\cline { 3 - 6 } & & $\begin{array}{c}|c| \\
\text { Frek } \\
\text { uens } \\
\text { i }\end{array}$ & $\begin{array}{c}\text { Perse } \\
\text { n }\end{array}$ & $\begin{array}{c}\text { Fre } \\
\text { kue } \\
\text { nsi }\end{array}$ & $\begin{array}{c}\text { Perse } \\
\mathrm{n}\end{array}$ \\
\hline 1 & $\begin{array}{l}\text { Bermain } \\
\text {-main, } \\
\text { sibuk } \\
\text { dengan } \\
\text { ceritanya } \\
\text { tidur- }\end{array}$ & 3 & 10,34 & 2 & 6,89 \\
\hline
\end{tabular}

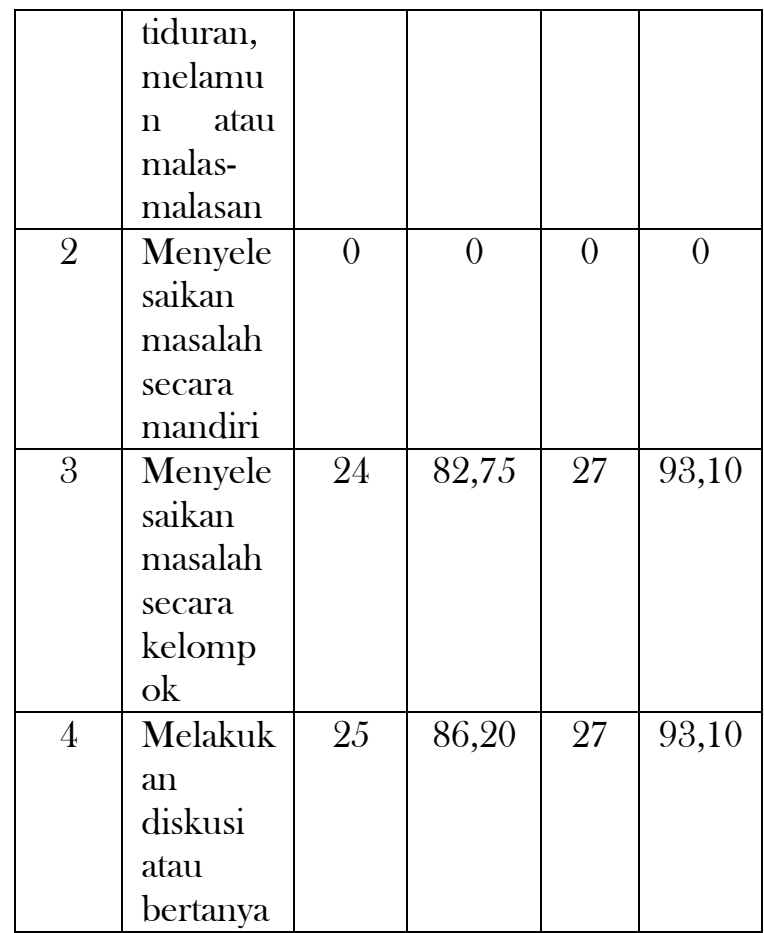

Sumber: Hasil olahan data lampiran 9 (N: 29 siswa)

Tabel 12. Aktivitas siswa pada guru yang mengajar dikelas XI.IPA.I Siklus II

\begin{tabular}{|c|c|c|c|c|c|}
\hline \multirow{3}{*}{ No } & \multirow{3}{*}{ Uraian } & \multicolumn{4}{|c|}{ Pengamat } \\
\hline & & \multicolumn{2}{|c|}{ I } & \multicolumn{2}{|c|}{ II } \\
\hline & & $\begin{array}{c}\text { Freku } \\
\text { ensi }\end{array}$ & $\begin{array}{l}\text { Pers } \\
\text { en }\end{array}$ & $\begin{array}{c}\text { Freku } \\
\text { ensi }\end{array}$ & $\begin{array}{c}\text { Pers } \\
\text { en }\end{array}$ \\
\hline 1 & $\begin{array}{l}\text { Berma } \\
\text { in- } \\
\text { main, } \\
\text { sibuk } \\
\text { dengan } \\
\text { ceritan } \\
\text { ya, } \\
\text { tidur- } \\
\text { tiduran } \\
\text { melam } \\
\text { un atau } \\
\text { malas- } \\
\text { malasa } \\
\text { n }\end{array}$ & 0 & 0 & 0 & 0 \\
\hline 2 & $\begin{array}{l}\text { Menye } \\
\text { lesaika }\end{array}$ & 0 & 0 & () & 0 \\
\hline
\end{tabular}

Vol. 7, No.1, April 2020, 93-109 |102 


\begin{tabular}{|c|c|c|c|c|c|}
\hline & $\begin{array}{l}\mathrm{n} \\
\text { masala } \\
\mathrm{h} \\
\text { secara } \\
\text { mandir } \\
\mathrm{i}\end{array}$ & & & & \\
\hline 3 & $\begin{array}{l}\text { Menye } \\
\text { lesaika } \\
\mathrm{n} \\
\text { masala } \\
\mathrm{h} \\
\text { secara } \\
\text { kelom } \\
\text { pok }\end{array}$ & 27 & 75 & 28 & $\begin{array}{c}77,7 \\
7\end{array}$ \\
\hline 4 & $\begin{array}{l}\text { Melak } \\
\text { ukan } \\
\text { diskusi } \\
\text { atau } \\
\text { bertan } \\
\text { ya }\end{array}$ & 29 & $\begin{array}{c}80,5 \\
5\end{array}$ & 31 & $\begin{array}{c}86,1 \\
1\end{array}$ \\
\hline
\end{tabular}

Sumber: Hasil olahan data lampiran 10 (N: 36 Siswa)

d. Tabel 13. Persepsi akhir siswa pada guru yang mengajar dikelas X. Satu

\begin{tabular}{|c|c|c|c|c|c|}
\hline Kelas & Siswa & $\begin{array}{c}\text { Ob } \\
\text { sio } \\
\text { n }\end{array}$ & $\begin{array}{c}\text { Persepsi } \\
\text { siswa }\end{array}$ & Persen & Ket \\
\hline \multirow{2}{*}{ X.I } & 2 & $\mathrm{~A}$ & 22 & 75,86 & \\
\cline { 3 - 5 } & & $\mathrm{B}$ & 5 & 17,24 & \\
\cline { 3 - 5 } & & $\mathrm{C}$ & 2 & 6,89 & \\
\cline { 3 - 5 } & & $\mathrm{D}$ & - & 0 & \\
\hline
\end{tabular}

Sumber : Hasil olahan data lampiran II(N: 29 Siswa)

e. Tabel 14. Persepsi Akhir siswa pada guru yang mengajar dikleas XI.IPA.1

\begin{tabular}{|c|c|c|c|c|c|}
\hline Kelas & Siswa & Obsion & $\begin{array}{c}\text { Persep } \\
\text { si } \\
\text { Siswa }\end{array}$ & $\begin{array}{c}\text { Pers } \\
\text { en }\end{array}$ & $\begin{array}{c}\text { K } \\
\text { e } \\
\text { t }\end{array}$ \\
\hline XI.IPA.1 & 36 & $\mathrm{~A}$ & 27 & 75 & \\
& & $\mathrm{~B}$ & 5 & $\begin{array}{c}13,8 \\
8\end{array}$ \\
& & $\mathrm{C}$ & 3 & 8,33 \\
& & $\mathrm{D}$ & 1 & 2,77 & \\
\cline { 3 - 5 } & & & & & \\
& & &
\end{tabular}

Sumber: Hasil olahan data lampiran 12 (N: 36 Siswa)

\section{2) Pembahasan}

Dari hasil analisa data tiap tabel pada bab terdahulu, berikut pada pembahasan hasil penelitian tindakan kepengawasan ini, peneliti akan menggambarkan apa adanya dari masingmasing siklus;

\section{Siklus Satu}

a. Persepsi Awal Siswa

1). Pada tabel nomor 3 diatas menunjukkan bahwa cara mengajar guru yang mengajar pafa kelas sepuluh satu (X.I) selama ini ada tujih orang siswa dengan 24,13 persen menyatakan senang cara mengajar gurunya dan ada 4 orang siswa yaitu 13,79 persen menyatakan kurang menyenangkan sedangkan yang menyatakan tidak senang ada 18 dengan 62,08 persen.

2). Pada tabel nomor 4 di atas yaitu guru yang mengajar dikelas sebelas IPA satu (XI.IPA.I) selama ini ada 2 orang siswa dengan 5,55 persen menyatakan sangat senang cara mengajar gurunya, yang menyatakan senang ada 8 orang siswa yaitu 22,22 persen dan ada 7 orang siswa yaitu 19,44 persen yang menyatakan kurang senang, berikutnya siswa yang menyatakan tidak senang ada 19 orang dengan 52,77 persen.

SMA Negeri 1 Polongbangkeng Utara (Polut) baru berumur kurang lebih 13 tahun dan memiliki 43 orang guru PNS. Guru yang mengajar dikelas sepuluh satu, pengalaman mengajarnya baru 5,6 tahun lebih, mengikuti suami yang bekerja disalah satu kantor daerah. Sedangkan guru yang mengajar dikelas XI.IPA.I bertempat tinggal agak jauh dari sekolah, mumpung seorang pria, dia berkendaraan roda dua pulang pergi dari rumah kesekolahnya, dia diperbantukan disalah satu wakasek oleh ibu kepala sekolah dari kedua guru tersebut diliriklirik administrasi perangkat pembelajarannya masih banyak-banyak menggunakan pada setiap pembahasan $\mathrm{KD} /$ sub KD cara-cara lama atau metode konvensional. Terbukti, guru yang mengajar di kelas X Satu siswa yang menyatakan kurang senang dan tidak senang seluruhnya ada 22 orang siswa dengan 75,86 persen, sedangkan guru yang mengajar dikelas XI.IPA Satu siswa yang menyatakan kurang senang dan tidak senang ada 26 orang siswa yaitu 72,22 persen. Dari hasil bincang-bincang peneliti dengan 2 orang siswa

Vol. 7, No.1, April 2020, 93-109|103 
yang mendapat rangking pada masing-masing kelas tersebut mereka mengungkapkan "Datang, Duduk" sering juga terjadi "Ditekan temantemanmu nak...."

b. Indikator kemampuan mengajar guru

1. Pada guru yang mengajar dikelas X.I

Dari tabel nomor 5 diatas menunjukkan bahwa guru yang mengajar dikelas X.I, pada kegiatan awal yang ada 6 butir item memperoleh skor 9, selanjutnya pada kegiatan inti memperoleh skor 14 dan pada kegiatan akhir memperoleh skor 5, diamatai dan diberikan oleh penilai pertama (peneliti) untuk penilaian kedua (penilai pendamping) memberikan skor masing-masing 10, 15, dan 5

Pada butir item nomor satu memperoleh skor 2, nilai kurang. Aksi guru tersebut begitu masuk kelas, menyuruh ketua kelas menyiapkan siswa untuk belajar, ditunggu selanjutnya dia tidak juga mengabsen siswa, duduk dikursi guru lalu membuka bukunya, menanyakan halaman berapa minggu lalu anakanak. Sehingga item butir nomor 2 memperoleh skor satu, dan item nomor 3 memperoleh juga skor satu. Dia tidak mengaitkan materi pembelajaran sebelumnya dengan materi sekarang yang akan diterangkan sehingga memperoleh skor 2, dan juga tidak menyampaikan tujuan pembelajaran serta tidak memotivasi siswa sehingga diberi skor satu, tidak juga memberikan kesempatan siswanya untuk bertanya, dia mendapat skor 2 . Kesimpulan pada kegiatan awal ini memperoleh nilai kurang.

Adapun pengamat kedua, kegiatan awal guru tersebut perolehan nilainya sama dengan pengamat pertama yaitu kurang. Pada butir item nomor 1, 3, 4, dan 6 memperoleh skor 2 dan pada butir nomor 2 , dan 5 memperoleh skor satu. Aksi guru yang mengajar dikelas X.I tersebut sama dengan pendapat pengamat I (Peneliti).

Lanjut pada kegiatan ini yang terdiri dari 8 butir item. Oleh pengamat I memberi skor 2 pada masing-masing butir item nornor 7,8,10,12 dan 13, sedangkan yang lainnya yaitu butir item nomor 9, 11, dan 14 mendapat skor satu. Pengajar hanya mendistribusi satu kali materi ajar yaitu buku LKS siswa disuruh buka lalu siswa disuruh membacanya tanpa ada kesempatan siswa bertanya, kesimpulan dikegiatan inti ini masih bernilai kurang.

Untuk pengamat kedua, pada kegiatan inti, ada kemiripan angka dalam menilai guru tersebut, tetapi bedanya ada pada butir item nomor 7 dan 8 yaitu memperoleh skor masingmasing 3 butir item nomor yang lainnya bernilai kurang yaitu masing-masing 2 .

Lanjut pada kegiatan akhir hanya butir item nomor 15 memperoleh skor 3, kategori cukup, itupun evaluasi yang dilakukan berupa aktivitas menjawab soal-soal yang ada pada buku LKS siswa secara tulis dan lisan. Sedangkan pada butir item nomor 16 dan 17 mendapat skor satu, kategori sangat kurang, guru tersebut tidak mempunyai catatan perolehan skor siswa dan tidak memberi ganjaran hadiah karena belum mengenal istilah ganjaran/hadiah, ucapnya lirih kepada peneliti setelah usai PBM, jumlah keseluruhan perolehan skor Oleh penilai pertama kepada guru yang mengajar dikelas X.I ada 28.

Sementara penilai / pengamat kedua, pada kegiatan akhir untuk butir item nomor 15 dan 16 memperoleh skor masing-masing 2 . butir item nomor 15 berbeda dengan pengamat/penilai pertama. Dimungkinkan pengamat kedua melihat kemalasan guru tersebut untuk membuat soal-soal dan butir item nomor 17 diberi skor satu sama dengan Pengamat pertama untuk pengamat/penilai kedua ini jumlah skor yang diberikan ada 31.jadi secara kumulatif perolehan skor dari kedua pengamat mendapat 29,5 dalam kategori kurang.

2. Pada guru yang mengajar dikelas XI.IPA.I

Melihat tabel nomor 6 diatas menunjukkan bahwa guru yang mengajar dikelas XI.IPA.I pada kegiatan awal memperoleh 13 dan pada kegiatan inti ada 16 , sedangkan pada kegiatan akhir memperoleh 5 . Oleh peneliti pertama ini memberi nilai perolehan skor 34. Adapunpengamat pendamping memberi skor masing-masing pada kegiatan awal 15 dan pada kegiatan inti 18 sedangkan dikegiatan akhir diberi 4. Jumlah skor perolehan oleh pengamat kedua ada 37.

Vol. 7, No.1, April 2020, 93-109 |104 
pengamat Pertama (Peneliti l), pada butir item nomor 1,4,6 diberi skor masing-masing 2. Guru kelas XI.IPA.I tersebut hanya datang mendekati ketua kelas beberapa temannya yang tidak hadir hari itu lalu menyuruh menyiapkan kelas dengan suara lantang dan keras dan disambut oleh teman-teman lainnya dengan memberi salam kepada pak gurunya secara bersemangat oleh penilai l. Memberi skor 3, begitu pula butir item nomor3 diberi juga skor 3 , sayang, butir nomor 4 dia hanya menanyakan materi minggu lalu itu Sampai dimana dan juga dia tidak memberi kesempatan pada siswanya untuk bertanya. Kendatipun demikian butir item nomor 5 tidak dilakukan sama sekali.

Adapun pengamat kedua, pada butir item nomor 2 dan 3 diberi skor masing-masing 4, kategori baik sedangkan butir item nomor 1,4 dan 5 diberi Skor masing-masing 2 sama dengan skor yang diberikan oleh pengamat pertama. Hanya saja pada butir item nomor 5 Pengamat pertama memberinya skor I. sedangkan dia (Pengamat 2) memberi skor 2. itu Dikarenakan ketika menanyakan materi pembelajaran lalu ada 2 orang siswa asyik ngobrol lalu ditegurnya dan berkata kalau mau belajar jangan main-main ya... sedang butir item nomor 6 pengamat kedua memberinya skor $\mathrm{I}$.

Lanjut, pengamat I pada butir item nomor 7,8,9,10,12 dan 14 memberi skor masing-masing 2, butir item 7,8 dan 12 hanya menyuruh kepada siswa menaikkan buku LKS lalu mengelompokkan siswa secara berpasangan dan menyuruh siswa membaca LKSnya, sehingga butir item nomor 13 diberi skor 3 dan sayang dia tidak melakukan pembimbingan. Pengamat kedua pada butir nomor item 8,9,10, dan 14 memberi skor masing-masing 2 karena mengajar dikelas XI.IPA. I kurang melakukan butir itemp tersebut sama dengan pengamat I diatas, hanya saja pada butir item nomor 7 dan 12 mendapat skor 3 karena siswa aktif disuruh membaca LKS nya, karena pengajar belum tahu membedakan kegiatan eksplorasi dengan kegiatan elaborasi sesuai permendiknas nomor 41 tahun 2007.

Pada kegiatan akhir pengamat I memberi skor 3 pada butir item nomor 15 dimana guru memberi soal-soal yang ada dalam LKS siswa sedangkan Pengamat Il memberi skor 2 alasan dimungkinkan sang guru sedikit malas Pada butir item nomor 16 dan 17 sama-sama mendapat skor I baik pengamat I dan Ke-2.

Diakhir pembelajaran, masing-masing pengamat yaitu pengamat I memberi skor 34 sedangkan pengamat II memberi skor 37. Jadi, secara kumulatif perolehan skor untuk guru yang mengajar dikelas XI.IPA.I ada 35,5. Kategori cukup.

C. Aktivitas siswa dalam kelas

l. Pada guru yang mengajar dikelas X.I

Dari tabel nomor 7 diatas menunjukkan bahwa pengamat I menilai guru yang mengajar pada kelad X.l yaitu frekuensi aktivitas siswa pada butir nomor 1 . Bermain main, sibuk dengan ceritanya .. dan seterusnya. ada 19 dengan 65.51 persen. Nlengapa? Karena guru tersebut kurang melakukan kontak mata artinya dia tidak mengabsen atau menanyakan siswanya yang tidak hadir. dia Iangsung mengajar sehingga pada menit-menit mulai awal sampai menitmenit ke 20-30 ada 7 orang siswa bermain-main (Berdiri mencolek temannya, menyentilnyentilkan tangan, dan bersiul-siul kecil), pada menit ke 30 dan 40 ada 3 orang siswa sibuk dengan ceritanya (Berbisik-bisik entah apa ceritanya) pada menit ke 40 dan 50 ada 2 orang siswa tidur-tiduran (Menundukkan kepalanya dimeja) dan pada menit ke 50 sampai 70 ada 7 orang siswa melamun dan malas-malasan (Tangannya didagunya dan beberapa kali menguak mulutnya karena mengantuk).

Sementara pengamat kedua, frekuensi aktivitas siswa tidak jauh beda dengan pengamat pertama yaitu ada 21 dengan 72,41 persen, letak perbedaannya ada pada menit pertama sampai 10 ada 4 orang siswa yang masih mainmain sedangkan pada menit ke 30 dan 40 ada 4 orang siswa sibuk dengan ceritanya. Pengamat I pada butir nomor 2 yaitu menyelesaikan masalah secara mandiri ada 23 orang siswa dengan 79,31 persen, ketika sang guru mulai memberi tugas kepada siswanya pada menitmenit ke 10 sampai seterusnya menit ke 70,80 dan 90 aktivitas siswa masih bekerja mandiri. Adapun pengamat ke dua, frekuensi aktivitas siswa tidak jauh beda dengan pengamat pertama yaitu ada 24 dengan 82,75 persen.

Vol. 7, No.1, April 2020, 93-109 |105 
Alhasil presentase pengamatan dari kedua orang pengamat dalam penelitian ini masing-masing : 1) .Bermain-main, sibuk dengan ceritanya, tidur-tiduran, melamun atau malas-malasan, secara kumulatif ada 68,96 persen. 2) Menyelesaikan masalah secara mandiri ada 81,03 persen. 3. Menyelesaikan masalah secara kelompok masing-masing pengamat memberi nol. 4. Melakukan diskusi atau bertanya juga masing-masing pengamat memberi nol.

Melihat butir nomor 1 dan 2 diatas, pada guru yang mengajar dikelas $\mathrm{X}$ satu kemampuan pengelolaan kelasnya masih lemah dan juga belum tertentu dengan salah satu model-model pembelajaran kooperatif bagaimana peserta didik dilibatkan dalam bekerja kelompok.

2.Pada Guru yang Mengajar di Kelas XI.IPA.1

Pada tabel nomor 8 di atas menunjukkan bahwa pengamat 1 menilai guru yang mengajar di kelas XI.IPA.1, yaitu frekuensi aktivitas siswa pada butir nomor 1, yakni bermain-main, sibuk dengan ceritanya... dan setersunya ada 23 siswa dengan 63,88 persen. Mengapa? Keyikaa ketua kelas menyiapakan teman-temannya untuk belajar atas perintah sang guru, sesudah itu HP sang guru berdering, lalu dijawab "Aku sedang mengajar”, jawabnya singka, lalu mengambil buku absennya menanyakan siswa yang tidak hadir, pada saat itu ada siswa yang bermain-main (saling mencubit dan tertawa-tawa kecil). Pada menit ke 20 sampai ke 30 ada 3 orang sibuk dengan ceritanya. Sementara pada menit ke 30 sampai ke 40 ada orang siswa tidur-tiduran (mungkin capek membantu orang tua bekerja, maklum areal sekolah tersebut banyak petani). Selanjutnya pada menit ke-40 sampai menit-menit ke 50-60 dan ke70 ada 10 orang siswa melamun dan malasmalasan. Adapun pengamat kedua menilai frekuensi aktivitas siswa memperolh 26 dengan 72,22 persen, ada beda 3 angka dengan pengamat 1, letak perbedaannya ada pada menit-menit pertama sampai ke 10 dan menit-menit ke 20 serta menit-menit ke 30-40 dan pada menit-menit ke 60-70.

Pengamat 1. Pada butir 2 yaitu menyelesaikan masalah secara mandiri ada 25 orang siswa dengan 69,44 persen. Pada waktu itu sang guru memberi instruksi ke siswanya agar bekerja berpasangan tanpa mengatur siswanya dalam bentuk kerja berpasangan, siswa memilih langsung temannya. Suasana agak bising sehingga ada lebih dari 10 orang yang tidak mendapat pasangan karena dikiranya mereka bekerja berpasangan sama dengan hari-hari yang lalu pada waktu belajar, sekitar 11 orang mereka belajar mandiri.

Adapun pengamat ke-2 frekuensi aktivitas siswa dalam menilai ada 28 orang siswa dengan 77,77 persen siswa bekerja berpasangan, selebihnya ada 8 orang siswa yang bekerja secara mandiri. Alhasil presentase pengamatan dari kedua pengamat dalam penelitian ini, masingmasing pada butir nomor satu secara kumulatif ada 68,05 persen. Pada butir nomor 2 secara kumulatif ada 73,605 persen. Sedangkan pada butir nomor 3 dan 4 yaitu menyelesaikan masalah secara kelompok dan melakukan diskusi atau bertanya masing-masing pengamat memberi nol. Pada guru yang mengajar di kelas XI.IPA.1 di atas, pengelolaan kelas yang dilakukannya sudah cukup mendingan tapi masih mau lebih ditingkatkan.

\section{Siklus Dua}

A. Indikator Kemampuan Mengajar Guru

1. Pada Guru yang Mengajar di Kelas X.I

Melihat tabel nomor 9 di atas pada guru yang mengajar di kelas X.I pengamat 1 menilai bahwa pada kegiatan awal yang terdiri dari 6 butir nomor memperoleh 19, dan pada kegiatan ini yang terdiri dari 8 item memperoleh 23, dan pada kegiatan akhir memperoleh 10. Jumlah perolehan guru tersebut ada 52. Adapun pengamat kedua memberi skor masing-masing : pada kegiatan awal 21, di kegiatan inti ada 23 dan kegiatan akhir diberi 11. Jumlah skor perolehan yang akan diberikan oleh pengamat kedua ada 52. Penilai 1 (penel;iti 1), pada butir item nomor 1,2,3,4, dan 5 pada lampiran 7 memberi nilai masing-masing 3,4,3,4, dan 3. Ketgori nilai cukup dan baik, dapat disebut ada peningkatan dalam proses pembelajaran dan sebelumnya setelah diberi pembimbingan dan pada butir

Item nomor 6 mendapat nilai dari kurang yaitu 2, dimungkinkan guru tersebut terlalu bersemangat sehingga lupa memberi kesempatan kepada siswanya. Adapun penilai

Vol. 7, No.1, April 2020, 93-109 |106 
(pengamat II) pada butir item nomor 1,2,3,4, dan 5 memberi nilai masing-masing 4,4,3,4 dan 4, sedikit lebih meningkat dari 1 . Tetapi, pada butir item nomor 6 nilainya sama yaitu 2. Lanjut, penilai pertama pada item butir-butir nomor 7,8 dan 9 memberi ekor masing-masing 2 . Mengapa?, Ibu guru kita hanya menginstruksikan kepada siswanya agar mencari teman-teman kelompoknya yang terbentuk pada 2 minggu lalu, nampak kelompok-kelompok belajar tersebut kurang heterogen, ini disebabkan mungkin faktor gengsi untuk menerima saran dari pengamat 1 dan 2. Sedangkan pada butir nomor item 12,13 dan 14 mendapat skor masing-masing 3,4 dan 3 . Kategori cukup dan baik. Adapun penilai kedua memberi skor pada butir item nomor 1,2,3,4 dan 5 masing-masing 4,4,3,4 dan 4, kategori baik dan cukup. Sedangkan pada butir item nomor 6 skornya 2 sama dengan penilai 1 diatas. Pada kegiatan inti dibutir-butir nomor 7,8 dan 9 diberi skor 3,4 dan 3, kategori cukup dan baik, sedangkan dibutir nomor 10 dan 11 diberi skor 2 dan 2, sama dengan penilai pertama diatas. Tetapi, pada butir item nomor 14 berbeda skornya yaitu diberi 2 kategori kurang. Karena guru tersebut aktivitasnya kurang mendatangi kelompok belajar apa ada permasalahan siswa kelompok atau tidak.

Pada kegiatan akhir baik penilai I maupun penilai ke II pada butir item nomor 15,16 dan 17 memberi skor mirip-mirip sama yaitu kategori cukup dan baik. Guru tersebut menunjukkan sudah ada kemampuan dan kesiapan melakukan evaluasi dan memberi semangat pada siswanya.

Dari kedua penilai jumlah skor yang diberikan masing-masing penilai I ada 52 dan penilai II ada 55. Jadi secara komulatif perolehan skor dari kedua pengamat dari siklus IIini mendapat 53,5 dalam kategori baik.

2. Pada guru yang mengajar dikelas XI.IPA.1

Pada kegiatan awal guru yang mengajar dikelas XI.IPA.1 oleh penilai Imemberi skor pada item butir nomor 1,2,3 dan 4 masing-masing 4,4,4 dan 4 kategori baik, nampak guru tersebut melakukannya dengan tenang dan sungguhsungguh. Dan pada butir item nomor 5 dan 6 mendapat skor 3,3 kategori cukup. Ini berarti ada perubahan sikap mengajar setelah mendapat pembimbingan dari peneliti.
Adapun pengamat II (pengamat pendamping)dibutir 1,2,3 dan 4 memberi skor masing-masing 4,4,5 dan 4. Yang membedakan antara pengamat II dengan pengamat I ada pada butir item nomor 3 yaitu skor 5 , ini menunjukkan guru tersebut menjelaskan $\mathrm{KD}$ atau sub KD dengan mantap, baik dan jelas, sedangkan pada butir item nomor 5 dan 6 mendapat skor 3,3 sama dengan penilai/pengamat I.

Lanjut pada butir item nomor-nomor 7,8,9,11,12 dan 14, penilai memberi skor masingmasing 3 sedangkan pada butir item nomor 10 dan 13 diberi skor masing-masing 4 dalam kategori cukup dan baik. Begitupula pengamat II pada kegiatan inti skor pada butir item-item nomor 7,8,11,12,13 masing-masing 4 sedangkan pada butir item nomor 9 dan 14 diberi skor 3, sama dengan pengamat I, kesempatan untuk menanggapi akan siswa-siswanya terhadap lembar LEKS yang dibagikan diberi nilai cukup, tetapi pada butir item nomor 10 mendapat skor 5 kategori amat baik, guru tersebut melakukannya sesuai dengan pembimbingan dari peneliti.

Lanjut pada kegiatan akhir oleh pengamat I dan pengamat II dibutir item nomor 15,16 dan 17 skor yang diberikan yaitu sama 3,4 dan 4. Jumlah skor penilai I ada 59 dan jumlah.

B. Aktifitas siswa didalam kelas

1. Pada guru yang mengajar dikelas X.1

Pada butir item nomor 2 yaitu menyelesaikan masalah secara mandiri oleh pengamat 1 memberi nilai persen nol, begitu pula pengamat dua juga memberi nol. Rupanya guru tersebut setelah mendapat bimbingan dari peneliti pada akhir-akhir menit ke 9 dan 10 setelah nomor item kegiatan awal selesai dan cepat-cepat mengorganisasikan siswanya dalam kerja kelompok sehingga siswanya tidak punya kesempatan untuk kerja mandiri.

Penilai 1 (pengamat 1) pada butir item nomor 3 frekuensi siswa melakukan kerja kelompok ada 24 siswa dengan 82,57 persen. Sedangkan pengamat II mengamati kerja kelompok ada 27 orang siswa dengan 93,10 persen. Dalam kerja kelompok tersebut siswasiswa aktif bertanya kepada sesama teman kelompoknya, ada yang aktif membaca materi lalu mendiskusikannya dan gurunya sebagai

Vol. 7, No.1, April 2020, 93-109 |107 
mediator, dan fasilitator senantiasa siap membimbing siswa-siswanya.

Sehingga pengamat I dan II pada kegiatan butir item nomor 4 yaitu melakukan diskusi atau bertanya menilai masing-masing pengamat I mencatat dan 25 orang siswa dengan 86,20 persen aktif berdiskusi dan bertanya sedangkan pengamat II mencatat ada 27 orang siswa dengan 93,10 persen melakukan hal yang sama.

Alhasil, presentasi pengamatan dari kedua penilai pengamat dalam penelitian ini masing-masing 1) Bermain-main, sibuk dengan ceritanya, tidur-tiduran, melamun atau malasmalasan, secara komulatif kedua pengamat memberi 8,61 persen. 2) Menyelesaikan masalah secara mandiri, kedua pengamat memberinya nol persen. 3) Menyelesaikan masalah secara kelompok, secara komulatif ada 87,92 persen. 4) Melakukan diskusi atau bertanya secara komulatif ada 89,65 persen.

2. Pada guru yang mengajar dikelas XI.IPA I

Akan halnya dengan guru ke-2, berdasarkan dari tabel nomoe 12, penilai atau pengamat I mengamati guru tersebut begitu masuk kelas melakukan kontak mata yang tajam dengan siswa-siswanya, tak seorangpun dari mereka berani berbisik-bisik atau ngobrol apalagi tidur-tiduran/bermalas- malasan, tiap fase dalam kegiatan awal dan inti maupun bagian akhir dilakukannya dengan mantap, baik dan benar sehingga pada butir item nomor 1dan 2 oleh masing-masing pengamat memberinya nol.

Adapun pada butir item nomor 3, yaitu menyelesaikan masalah kelompok oleh penilai I memberi frekuensi persen 27 dengan 75 persen dan oleh penilai II memberi 28 dengan 77,77 persen. Sedangkan pada butir item nomor 4 yaitu melakukan diskusi atau bertanya, oleh penilai I mencatat ada 29 orang siswa dengan 80,55 persen aktif berdiskusi dan bertanya, dan oleh penilai II mencatat ada 31 orang siswa dengan 86,11 persen siswa melakukan hal yang sama diatas.

Secara kumulatif kedua pengamat memberi nol 2). Begitu pula menyelesaikan masalah secara mandiri kedua mengamat memberinya nol. 3). Menyelesaikan masalah secara kelompok, secara kumulatif ada 76,38 persen. 4). Melakukan diskusi atau bertanya, secara kumulatif ada 83,33 persen.
C. Persepsi Akhir Siswa

1. Melihat tabel 13 diatas dimana guru yang mengajar dikelas X.I menunujukkan bahwa ada 22 orang siswa sekitar 75,86 persen menyatakan sangat senang diajar oleh gurunya dengan menggunakan salah satu pembelajaran kooperatif yaitu kooperatif STAD. Selanjutnya ada 5 orang siswa dengan 17,24 persen menyatakan senang, dan ada 2 orang siswa sekitar 6,89 persen menyatakan kurang senang, sedangkan yang menyatakan tidak senang nol siswa.

2. Adapun pada tabel nomor 14 diatas, gurunya mengajar dikelas XI.IPA.1 menunjukkan bahwa ada 27 orang siswa dengan 75 persen menyatakan sangat senang dengan pembelajaran model kooperatif STAD. Dan ada 5 orang siswa sekitar 13,88 persen menyatakan kurang senang ada 3 orang siswa sekitar 8,33 persen dan menyatakan tidak senang ada 1 orang yaitu 2,77 persen.

Alhasil guru pertama diatas kategori sangat senang dan senang ada sekitar 93,1 persen dan pada guru yang kedua kategori sangat senang dan senang ada sekitar 88,88 persen. Hasil bincang-bincang dengan 1.2, orang siswa pada setiap kelas setelah usai memantau mereka mengungkapkan "Cobanya semua guru-guru begini cara mengajarnya bu..." ungkap salah seorang temannya "Enak ya bu... kami bersemangat bu..." lanjut temannya yang berdiri disamping peneliti. Ketika berada diruangan kepala sekolah, peneliti sempat bertanya kepada ke-2 responden tersebut. Spontan salah seorang menjawab "Enak buu.... Dengan model pembelajaran kooperatif STAD"

\section{E. Kesimpulan}

Tulisan penelitian tindakan sekolah ini adalah sebagai upaya pengawas sekolah mata pelajaran sejarah dalam meningkatkan kemampuan guru-guru sejarah melaksanakan pembelajaran dikelas dengan menggunakan salah satu model pembelajaran kooperatif tipe STAD di SMA Negeri 1 Polongbangkeng Utara Kabupaten Takalar. Berdasarkan hasil analisis data dan pembahasan yang telah dipaparkan pada bab sebelumnya, tulisan ini dapat disimpulkan sebagai berikut.

Vol. 7, No.1, April 2020, 93-109 |108 
A) Persepsi awal dan akhir siswa

a. Pada guru yang mengajar dikelas X.I Ada perubahan sikap belajar siswa terhadap cara mengajar gururnya dari tidak senang sekitar 62,08 persen pada siklus I menjadi sangat senang sekitar 75,86 persen pada siklus II. Ada kenaikan sekitar 13,78 persen.

b. Pada guru yang mengajar dikelas XI.IPA.1 Ada perubahan sikap belajar siswa terhadap cara mengajar gurunya dari tidak senang sekitar 52,77 persen pada sekitar 52,77 persen pada siklus I, menjadi sangat senang sekitar 75 persen pada siklus II, ada kenaikan sekitar 22,23 persen.

B) Kemampuan Mengajar Guru

ada perubahan sikap dan cara mengajar guru dikelas X.I dari kategori kurang sekitar 29,5 pada siklus I, menjadi kategori baik sekitar 53,5 pada siklus II. Ada kenaikan skor sekitar 24.

\section{Daftar Pustaka}

Armai arief, 2007, Ilmu Pengetahuan dan Teknologi (IPTEK) PT.Bumi Aksara Jakarta.

Anonim, 2006. Standar Isi KTSP Tahun2006 Mata Pelajaran Sejarah untuk SMA/MA, BSNP,Jakarta

Anonim, 2007, Permendiknas RI No. 41, Tahun 2007 Tentang Standar Proses BSNP, Jakarta

Asri Budiningsih, 2005. Belajar Dan Pembelajaran. PT. RINEKA CIPTA, Jakarta

Arikunto, Suharsini, 2005. Materi Penelitian Tindakan Kelas (C.A.R) Depdiknas Direktorat Jenderal Pendidikan dasar dan Menengah, Direktora tenaga Kependidikan, Jakarta

L.P.M.P Makassar 2005, Model- Model Pembelajaran Inovatif, Pelatihan terintegrasi berbasis kompetensi, SeSul-Bar, Kopain Makassar

Maesuri, 2002. Apa yang Sungguh baru dalam perangkat pembelajaran berbasis C.R.L,.............., Makalah UNESA.

Suradi, 2005. Interaksi siswa dalam pembelajaran disertai PPS UNESA Surabaya.
Suradi. MS,Dkk 2006. Model pembelajaran

kooperatif, apa, mengapa dan bagaimana, LPMP

Provinsi Sul-Sel.

Slavin, Robert 1995. Cooperative Learning Theory Research dan Prctice, Frouth Edition,

Bostan; Allyn and Bacon.

Sugiyono, 2007 Metode Penelitian Administrasi dilengkapi dengan metode R\&D. CV. Alfabeta

Bandung. 